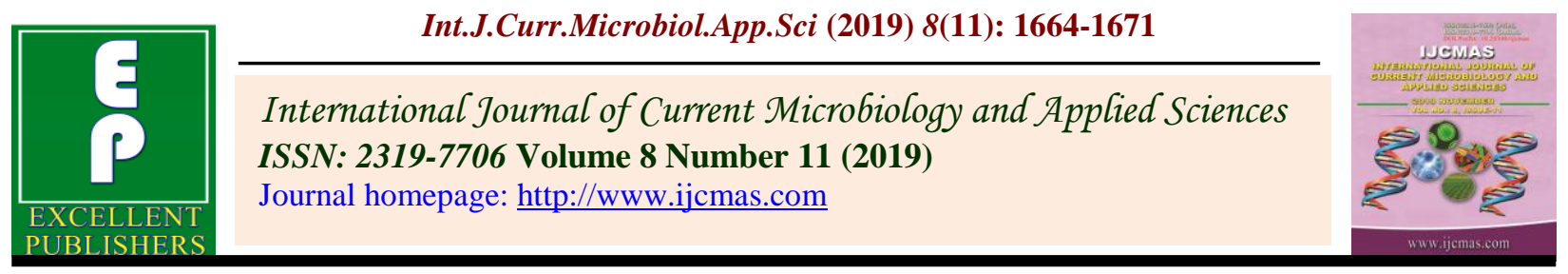

Original Research Article

https://doi.org/10.20546/ijcmas.2019.811.193

\title{
Interactive and Individual Effect of Boron and Potassium on under Developed Nuts, Shed Nuts and Split Nuts of Arecanut in Terai Region of West Bengal, India
}

\author{
B.V.Supriya ${ }^{1 *}$,P.S. Medda ${ }^{1}$ and A.K. Sinha ${ }^{2}$ \\ ${ }^{1}$ Department of Plantation, Spices, Medicinal and Aromatic Crops, Faculty of Horticulture, \\ ${ }^{2}$ Department of Soil Science and Agriculture Chemistry, Faculty of Agriculture, Uttar Banga \\ Krishi Vishwavidyalaya, Punibari, West Bengal, India \\ *Corresponding author
}

Keywords

Arecanut, Boron, Potassium, Under developed nuts, Shed nuts and split nuts

Article Info

Accepted:

12 October 2019

Available Online:

10 November 2019

\section{A B S T R A C T}

The experiment was conducted during the year 2017-18 at the instructional farm of Department of Plantation Crops and Processing, Faculty of Horticulture, Uttar Banga Krishi Vishwavidyalaya, West Bengal. The study was aimed to evaluate the effect of graded level application of boron and potassium and their interaction on under developed nuts, shed nuts and split nuts of terai region of West Bengal. The experiment was carried out in a $2.7 \times 2.7 \mathrm{~m}$ spaced 12 year old planted with $\mathrm{cv}$. Mohitnagar and laid out in factorial RBD having 12 treatments replicated 4 times with 4 different level of boron viz., $\mathrm{B}_{0}, \mathrm{~B}_{1}, \mathrm{~B}_{2}$ and $\mathrm{B}_{3}$ at $0 \mathrm{~g}, 25 \mathrm{~g}, 50 \mathrm{~g}$ and sprayed with $4 \% \mathrm{Na}_{2} \mathrm{~B}_{4} \mathrm{O}_{7}$ solution along with 3 different level of potassium $\left(\mathrm{K}_{2} \mathrm{O}\right)$ viz., $\mathrm{K}_{1}, \mathrm{~K}_{2}$ and $\mathrm{K}_{3}$ at $70 \mathrm{~g}, 140 \mathrm{~g}, 210 \mathrm{~g}$ of $\mathrm{K}_{2} \mathrm{O}$ per palm respectively to the bunches at $2^{\text {nd }}, 4^{\text {th }}$ and $6^{\text {th }}$ months respectively per palm at nut development stage at regular intervals. Soil and nut samples are collected from 10 equidistant spots and 10 different palms respectively where as leaf sample is collected from the $4^{\text {th }}$ index leaf (Ravi Bhat and Sujatha, 2014) from 10 equidistant palms for analysis before and after application of treatments. The results revealed that graded level application of boron and potassium shows that at higher level of boron $\left(\mathrm{B}_{2}\right)$ shows increased potassium content in the soil and nut where as at (B1) the potassium content of the leaf showed highest and at (K3) the potassium content of the soil and nut showed highest potassium and at $\mathrm{K} 2$ level the potassium content of leaf is gradually increased $(\mathrm{mg} / \mathrm{kg})$ and their interaction effect shows that, higher level combination of both boron and potassium $\left(\mathrm{B}_{2} \mathrm{~K}_{3}\right)$ shows higher potassium content in the soil and nut $(\mathrm{mg} / \mathrm{kg})$ and also 0 level of boron and highest level of potassium showed increased potassium content in the leaf $\left(\mathrm{B}_{0} \mathrm{~K}_{3}\right)$ and also at $\mathrm{B}_{3} \mathrm{~K}_{2}$ and $\mathrm{B}_{2} \mathrm{~K}_{2}$ level of interaction the yield parameters like (fresh kernel weight and dry kernel weight) shows significant effect. 


\section{Introduction}

The Arecanut is the fruit of the areca palm (Areca catechu) popularly known as betelnut belongs to family arecaceae which grows in much of the Tropical pacific (Melanasia and Micronesia), South East Asia and South Africa. It is mainly chewed with the betel leaves, lime, with or without tobacco. The value added form of consumption is by way of pan masala and scented supari. The nut has got some medicinal and neutracritical properties. It is health activator, mouth freshner and has digestive properties. Arecanut can be used for the following purposes like masaj powder, soaps and shampoos, cosmetics, antihelmintic and antidiabetic, areca wine making, areca soft drink, ayurvedic type of thamboola for chewing purpose, ulcer healing combination, hair oil and dyes, food colours and skin ointments (Prakash, 2010).

Soil fertility is one of the important factors controlling the crop yield; soil related limitations affecting the crop productivity including nutritional disorders can be determined by evaluating the fertility status of soils. Soil testing provides the information about the nutrient availability of the soil upon which the fertilizer recommendation for maximizing crop yield is made.

Under developed nuts are obtained may be because of lack of better pollination and also due to lack of irrigation and also may be due to lack of nutrient availability and competition among the developing nuts causing barrier for good nut development.

Nut shedding may occur due to some abiotic stresses like rainfall, wind etc. and also shedding may occur due to nutrient imbalance especially. It is calculated by substracting from the number of fruits reaches its ripening stage to the number of fruits set initially. Nut splitting is one of the physiological disorder rather than physiological disease, it is characterized by the cracking fruits known as 'Anduadakke roga' in kannada, the disease is known as 'Achikeeral' in kerala. This is abnormally seen in patches in individual gardens and is common in young plants, it is caused due to nutrient deficiencies due to low potassium availability (Bhat and Sujatha, 2014).

Boron and Potassium nutrients plays a vital role in the growth and development of arecanut palm where all palms are potassium lovers, required in larger quantity for the development of nuts etc., hence it has to be supplied to the plants in the adequate quantity, both excess supply of minerals and limited supply of nutrients leads to different problems. Due to nutrient deficiency in Terai region soil the plantation under this region are showing greater extent of potassium and boron deficiency which directly effect on nut development which is leading to nut fall, which ultimately reduces the yield of the crop.

\section{Materials and Methods}

The experiment was carried out during 201718 at the Instructional Plots of the Department of Plantation Crops and Processing, Uttar Banga Krishi Viswavidyalaya, West Bengal. Physico-chemical properties of the soil analysed by standard methods were soil texture- sandy loam, pH - 5.45 (Jackson, 1973), electrical conductivity - 0.06 dsm- 1 (Jackson, 1973), available $\mathrm{N}-159.62 \mathrm{~kg} / \mathrm{ha}$ (Alkaline $\mathrm{KMnO}_{4}$ method, Subbiah and Asija, 1956), available $\mathrm{P}-23.15 \mathrm{~kg} / \mathrm{ha}$ (Acid extractable method, Bray and Kurtz, 1945), available $\mathrm{K}-145.3 \mathrm{~kg} / \mathrm{ha}$ (1N ammonium acetate method, Jackson, 1967), and available B - $1.77 \mathrm{mg} / \mathrm{kg}$ (Hot water extractable as proposed by Berger and Truog (1939). The experiment was laid out in Factorial Randomised Block Design with 12 treatments 
replicated 4 times with 4 different level of boron viz., $\mathrm{B}_{0}, \mathrm{~B}_{1}, \mathrm{~B}_{2}$ and $\mathrm{B}_{3}$ at $0 \mathrm{~g}, 25 \mathrm{~g}, 50 \mathrm{~g}$ and sprayed with $4 \% \quad \mathrm{Na}_{2} \mathrm{~B}_{4} \mathrm{O}_{7}$ solution along with 3 different level of potassium $\left(\mathrm{K}_{2} \mathrm{O}\right)$ viz $\mathrm{K}_{1}, \mathrm{~K}_{2}$ and $\mathrm{K}_{3}$ at $70 \mathrm{~g}, 140 \mathrm{~g}, 210 \mathrm{~g}$ of $\mathrm{K}_{2} \mathrm{O}$ per palm respectively to the bunches at $2^{\text {nd }}, 4^{\text {th }}$ and $6^{\text {th }}$ months respectively per palm at nut development stage at regular intervals.

All the palms which are under treatment had given Nitrogen, Phosphorous, potassium and the boron in the form of urea (46\%), single super phosphate $\left(\begin{array}{lll}16 \% & \mathrm{P}_{2} \mathrm{O}_{5}\end{array}\right)$, muriate of potash $\left(60 \% \mathrm{~K}_{2} \mathrm{O}\right)$ and Borax $(10.5 \% \mathrm{~B})$ respectively. According to the treatment details, the plams were applied with 4 different level of boron viz., $\mathrm{B}_{0}, \mathrm{~B}_{1}, \mathrm{~B}_{2}$ and $\mathrm{B}_{3}$ at $0 \mathrm{~g}, 25 \mathrm{~g}, 50 \mathrm{~g}$ and sprayed with $4 \% \mathrm{Na}_{2} \mathrm{~B}_{4} \mathrm{O}_{7}$ solution along with 3 different level of potassium $\left(\mathrm{K}_{2} \mathrm{O}\right)$ viz., $\mathrm{K}_{1}, \mathrm{~K}_{2}$ and $\mathrm{K}_{3}$ at $70 \mathrm{~g}$, $140 \mathrm{~g}, 210 \mathrm{~g}$ of $\mathrm{K}_{2} \mathrm{O}$ per palm respectively to the bunches at $2^{\text {nd }}, 4^{\text {th }}$ and $6^{\text {th }}$ months respectively per palm at nut development stage at regular intervals. A constant dose of Nitrogen was applied in the form of Urea at $109 \mathrm{~g} / \mathrm{palm}$ and phosphorous $\left(\mathrm{P}_{2} \mathrm{O}_{5}\right)$ at $125 \mathrm{~g} / \mathrm{palm}$ in two equal splits at pre and post monsoon.

Fertilizer are applied in basins around the palm dug to a depth of $15-20 \mathrm{~cm}$ and $0.75-1.0$ $\mathrm{m}$ radius from the base of the palm and after the application to the basins were thoroughly mixed with the soil and covered with the top soil. The fertilizer application as stated was followed with light irrigation (Nathanael, 1967 and Dew Saliva, 1968). The initial soil samples $0-15 \mathrm{~cm}$ and $15-30 \mathrm{~cm}$ depth were collected randomly throughout the experimental plots before commencement of application of fertilizers mentioned in the experimental details. The soil samples were drawn from the selected from a Dutch Auger (Make: AIC Agro-Industries Private Ltd, Kolkata) as initial sample and later as final sample after the completion of experiment.
The sample were collected from base of each palm as separate treatment according to the replication and maintained separately for analysis. In the process, the bulk soil was reduced to $1 \mathrm{~kg}$ by following the quartering method. This $1 \mathrm{~kg}$ soil sample constituted the composite soil sample. The composite soil samples were then air dried, passed through a $2 \mathrm{~mm}$ sieve and stored in clean dry cloth bags with adequate descriptions in attached paper labels. All relevant information and identification marks as required were also recorded. These composite soil samples were analysed in the laboratory for the required soil characteristics and properties and some of the parameters like $\mathrm{pH}$ (Jackson, 1973), electrical conductivity (Jackson, 1973), available N (Alkaline $\mathrm{KMnO}_{4}$ method, Subbiah and Asija, 1956), available P (Acid extractable method, Bray and Kurtz, 1945), available (1N ammonium acetate method, Jackson, 1967), and available B (Hot water extractable as proposed by Berger and Truog (1939) has been analysed and also Leaf samples were collected from the $4^{\text {th }}$ index leaf (Bhat and Sujatha, 2014) from 10 equidistant palms for analysis before application of the fertilizer and after completion of the experiment from each palm as per the treatment, 4 samples were collected from each treatment and the bulking of sample and kept separately for analysis and then determination of boron and potassium content in the leaf sample were done.

The collected leaf samples were brought to the laboratory and washed immediately with tap water and then rinsed with $0.1 \mathrm{~N} \mathrm{HCl}$. The washed and rinsed samples were dried under shade followed by oven drying at a temperature of $65 \pm 5^{\circ} \mathrm{C}$ so as to reduce the chemical and biochemical changes to the minimum. The oven dried samples were powdered and stored in butter paper bags for chemical analysis. In the same way nut samples were collected after oven drying the dehusked arecanut, the kernel was dried 
separately in the oven after separating husk and kernel and then the kernel was grinded, powdered again oven dried and it was kept separately according to the treatment with its replication and proceeded for analysis for both leaf and nut samples of both boron and potassium content has been analysed using Azomethin- $\mathrm{H}$ method and wet digestion method by using tri-acid respectively.

\section{Results and Discussion}

Effect of boron and potassium and their interaction on number of underdeveloped nuts, shed nuts and split nuts during the course of nut development per palm

Effect of boron and potassium on number of under developed nuts and their interaction during the course of experiment per palm

Under developed nuts are obtained may be because of lack of better pollination and also due to lack of irrigation and also may be due to lack of nutrient availability and competition among the developing nuts causing barrier for good nut development.

As per the data obtained from the analysis showed a significant variation with regard to under developed nuts per palm) i.e., zero level boron application resulted significantly higher underdeveloped nuts (12.33) and $\mathrm{B}_{3}$ shows significantly lower level of under developed nuts may be direct spraying of boron in bunch at lower level of soil and plant boron but higher than critical level $25-55 \mathrm{mg} / \mathrm{kg}$ (Bhat and Sujatha, 2014) played an important role in pollination and consequent nut development and as per the different graded level of potassic fertilizers $K_{1}$ (7.17) showed higher underdeveloped nuts and $\mathrm{K}_{3}$ showed lower (5.50) under developed nuts might be due to antagonistic role of boron and potassium at higher level. The interaction effect of both boron and potassium effect together at different graded levels also resulted significant variation. The treatment $\mathrm{B}_{0} \mathrm{~K}_{2}$ (15.33) showed higher underdeveloped nuts followed by $\mathrm{B}_{0} \mathrm{~K}_{3}$ (13.33) and $\mathrm{B}_{1} \mathrm{~K}_{1}$.

But all the treatments when applied at bunch at 2 months interval irrespective of potassium application resulted significantly lower under developed.

Effect of boron and potassium on number of Shed nuts during the course of experiment per palm

Nut shedding may occur due to some abiotic stresses like rainfall, wind etc. and also shedding may occur due to nutrient imbalance especially. It is calculated by substracting from the number of fruits reaches its ripening stage to the number of fruits set initially.

As per the application of boron, data revealed that $\mathrm{B}_{0}$ at zero level of application shows maximum shedding nut (140.11) which as statistically at par with $\mathrm{B}_{1}$ and $\mathrm{B}_{3}$ level of boron application, so it shows boron plays important role in nut shedding and it corrected by boron application at different levels as mentioned in the experiment, by the same way $\mathrm{B}_{2}$ level shows significantly lower (77.56) shedding of nuts and at different level of potassium application showed that $\mathrm{K}_{1}$ (141.17) (Table 1; Fig. 1) shows significantly higher shed nuts and $\mathrm{K}_{2}$ level resulted significantly lower shed nut (66.25). The combined effect of both $\mathrm{B}$ and $\mathrm{K}$ application data revealed that $\mathrm{B}_{0} \mathrm{~K}_{3}$ showed significantly higher shedding of nuts (199.33) followed by $\mathrm{B}_{1} \mathrm{~K}_{1}$ (181.00) (Table 2) (Fig. 2) and $\mathrm{B}_{1} \mathrm{~K}_{3}$ (176.33) which might be due to nutrient imbalance at that level but $\mathrm{B}_{2} \mathrm{~K}_{2}$ level shows significantly lower shedding of nuts (28.00) due to moderate uptake of boron (171.167 mg/kg) (Fig. 2) and potassium $(3388.20 \mathrm{mg} / \mathrm{kg})$ by the plants and reached equilibrium. 
Effect of boron and potassium application on number of Split nuts during the course of experiment per palm

Nut splitting is one of the physiological disorder rather than physiological disease, it is characterized by the cracking fruits known as
'Anduadakke roga' in kannada, the disease is known as 'Achikeeral' in Kerala. This is abnormally seen in patches in individual gardens and is common in young plants, it is caused due to nutrient deficiencies due to low potassium availability (Bhat and Sujatha, 2014).

Table.1 The 12 different treatment combinations were as follows

\begin{tabular}{|c|c|}
\hline$T_{1}: \mathbf{B}_{0} K_{1}$ & $0 \mathrm{~g}$ borax/palm $(0 \mathrm{~g} \mathrm{~B})+70 \mathrm{~g} \mathrm{~K}$ (O/palm \\
\hline $\mathbf{T}_{2}: \mathbf{B}_{0} \mathbf{K}_{2}$ & $0 \mathrm{~g}$ borax/palm $(0 \mathrm{~g} \mathrm{~B})+140 \mathrm{~g} \mathrm{~K}_{2} \mathrm{O} / \mathrm{palm}$ \\
\hline $\mathbf{T}_{3}: \mathbf{B}_{0} \mathbf{K}_{3}$ & $0 \mathrm{~g}$ borax/palm $(0 \mathrm{~g} \mathrm{~B})+210 \mathrm{~g} \mathrm{~K}_{2} \mathrm{O} / \mathrm{palm}$ \\
\hline $\mathbf{T}_{4}: \mathbf{B}_{1} \mathbf{K}_{1}$ & $25 \mathrm{~g}$ borax/palm $(2.63 \mathrm{~g} \mathrm{~B})+70 \mathrm{~g} \mathrm{~K}_{2} \mathrm{O} /$ palm \\
\hline $\mathbf{T}_{5}: \mathbf{B}_{1} \mathbf{K}_{2}$ & $25 \mathrm{~g}$ borax/palm $(2.63 \mathrm{~g} \mathrm{~B})+140 \mathrm{~g} \mathrm{~K}_{2} \mathrm{O} /$ palm \\
\hline$T_{6}: B_{1} K_{3}$ & $25 \mathrm{~g}$ borax/palm $(2.63 \mathrm{~g} \mathrm{~B})+210 \mathrm{~g} \mathrm{~K}_{2} \mathrm{O} /$ palm \\
\hline $\mathbf{T}_{7}: \mathbf{B}_{2} \mathbf{K}_{1}$ & $50 \mathrm{~g}$ borax/palm $(5.25 \mathrm{~g} \mathrm{~B})+70 \mathrm{~g} \mathrm{~K}_{2} \mathrm{O} /$ palm \\
\hline $\mathbf{T}_{8}: \mathbf{B}_{2} \mathbf{K}_{2}$ & $50 \mathrm{~g}$ borax/palm $(5.25 \mathrm{~g} \mathrm{~B})+140 \mathrm{~g} \mathrm{~K}_{2} \mathrm{O} /$ palm \\
\hline $\mathbf{T}_{9}: \mathbf{B}_{2} \mathbf{K}_{3}$ & $50 \mathrm{~g}$ borax $/$ palm $(5.25 \mathrm{~g} \mathrm{~B})+210 \mathrm{~g} \mathrm{~K}_{2} \mathrm{O} /$ palm \\
\hline $\mathbf{T}_{10}: \mathbf{B}_{3} \mathbf{K}_{1}$ & Spray $0.4 \% \mathrm{Na}_{2} \mathrm{~B}_{4} \mathrm{O}_{7}+70 \mathrm{~g} \mathrm{~K}_{2} \mathrm{O} /$ palm \\
\hline $\mathbf{T}_{11}: \mathbf{B}_{3} \mathbf{K}_{2}$ & Spray $0.4 \% \mathrm{Na}_{2} \mathrm{~B}_{4} \mathrm{O}_{7}+140 \mathrm{~g} \mathrm{~K}_{2} \mathrm{O} /$ palm \\
\hline $\mathbf{T}_{12}: \mathbf{B}_{3} K_{3}$ & Spray $0.4 \% \mathrm{Na}_{2} \mathrm{~B}_{4} \mathrm{O}_{7}+210 \mathrm{~g} \mathrm{~K}_{2} \mathrm{O} /$ palm \\
\hline
\end{tabular}

Table.2 Effect of boron and potassium on number of underdeveloped nuts, shed nuts and split nuts during the course of nut development per palm

\begin{tabular}{|c|c|c|c|}
\hline Treatment & $\begin{array}{c}\text { Under developed } \\
\text { nuts/palm }\end{array}$ & $\begin{array}{c}\text { Shed nut during the } \\
\text { course of nut } \\
\text { development/palm }\end{array}$ & $\begin{array}{c}\text { Split nut during the } \\
\text { course of } \\
\text { development/palm }\end{array}$ \\
\hline B0 & 12.33 & 140.11 & 3.55 \\
\hline B1 & 6.44 & 139.78 & 1.44 \\
\hline B2 & 3.22 & 77.56 & 0.79 \\
\hline B3 & 2.44 & 105.78 & 0.67 \\
\hline S.Em( \pm ) & $\mathbf{0 . 5 6}$ & $\mathbf{1 9 . 7 9}$ & $\mathbf{0 . 2 8}$ \\
\hline C.D. $(\mathbf{0 . 0 5})$ & $\mathbf{1 . 6 4}$ & $\mathbf{5 8 . 0 3}$ & $\mathbf{0 . 7 5}$ \\
\hline K1 & 7.17 & 141.17 & 0.58 \\
\hline K2 & 5.67 & 66.25 & 0.92 \\
\hline K3 & 5.50 & 140.00 & 3.33 \\
\hline S.Em( $(\mathbf{)}$ & $\mathbf{0 . 4 9}$ & $\mathbf{1 7 . 1 3}$ & $\mathbf{0 . 2 2}$ \\
\hline C.D.(0.05) & $\mathbf{1 . 4 2}$ & $\mathbf{5 0 . 2 5}$ & $\mathbf{0 . 6 5}$ \\
\hline
\end{tabular}


Table.3 Interaction effect of boron and potassium application on number of underdeveloped nuts, shed nuts and split nuts during the course of nut development per palm

\begin{tabular}{|c|c|c|c|}
\hline Treatment & $\begin{array}{c}\text { Under developed } \\
\text { nuts/palm }\end{array}$ & $\begin{array}{c}\text { Shed nut during the } \\
\text { course of nut } \\
\text { development/palm }\end{array}$ & $\begin{array}{c}\text { Split nut during the } \\
\text { course of } \\
\text { development/palm }\end{array}$ \\
\hline $\mathbf{B}_{\mathbf{0}} \mathbf{K}_{\mathbf{1}}$ & 8.33 & 125.33 & 3.33 \\
\hline $\mathbf{B}_{\mathbf{0}} \mathbf{K}_{\mathbf{2}}$ & 15.33 & 95.67 & 1.33 \\
\hline $\mathbf{B}_{\mathbf{0}} \mathbf{K}_{\mathbf{3}}$ & 13.33 & 199.33 & 2.33 \\
\hline $\mathbf{B}_{\mathbf{1}} \mathbf{K}_{\mathbf{1}}$ & 10.67 & 181.00 & 0.66 \\
\hline $\mathbf{B}_{\mathbf{1}} \mathbf{K}_{\mathbf{2}}$ & 3.67 & 62.00 & 0.33 \\
\hline $\mathbf{B}_{\mathbf{1}} \mathbf{K}_{\mathbf{3}}$ & 5.00 & 176.33 & 3.33 \\
\hline $\mathbf{B}_{\mathbf{2}} \mathbf{K}_{\mathbf{1}}$ & 6.67 & 96.67 & 1.33 \\
\hline $\mathbf{B}_{\mathbf{2}} \mathbf{K}_{\mathbf{2}}$ & 3.00 & 28.00 & 1.67 \\
\hline $\mathbf{B}_{\mathbf{2}} \mathbf{K}_{\mathbf{3}}$ & 0.00 & 108.00 & 7.66 \\
\hline $\mathbf{B}_{\mathbf{3}} \mathbf{K}_{\mathbf{1}}$ & 3.00 & 161.67 & 0.33 \\
\hline $\mathbf{B}_{\mathbf{3}} \mathbf{K}_{\mathbf{2}}$ & 0.67 & 79.33 & 1.66 \\
\hline $\mathbf{B}_{\mathbf{3}} \mathbf{K}_{\mathbf{3}}$ & 3.67 & 76.33 & 0.00 \\
\hline S.Em(土) & $\mathbf{0 . 9 7}(\mathbf{E} \mathbf{m}$ & $\mathbf{3 4 . 2 7}$ & $\mathbf{0 . 4 4}$ \\
\hline C.D.(0.05) & $\mathbf{2 . 8 5}$ & $\mathbf{1 0 0 . 5 0}$ & $\mathbf{1 . 3 0}$ \\
\hline
\end{tabular}

Fig.1 Effect of boron and potassium application on number of underdeveloped nuts, shed nuts and split nuts during the course of nut development per palm

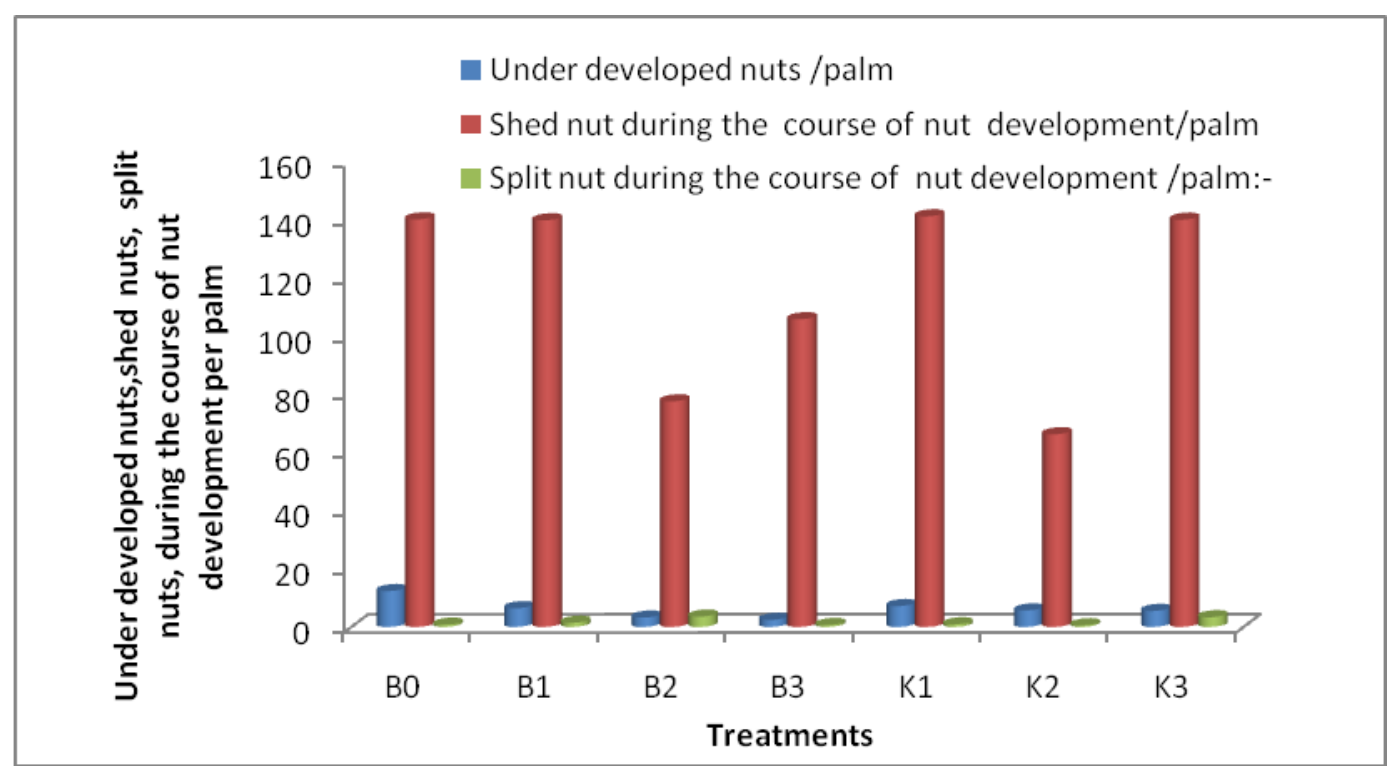


Fig.2 Effect of boron and potassium application and their interaction number of underdeveloped nuts, shed nuts and split nuts during the course of nut development per palm

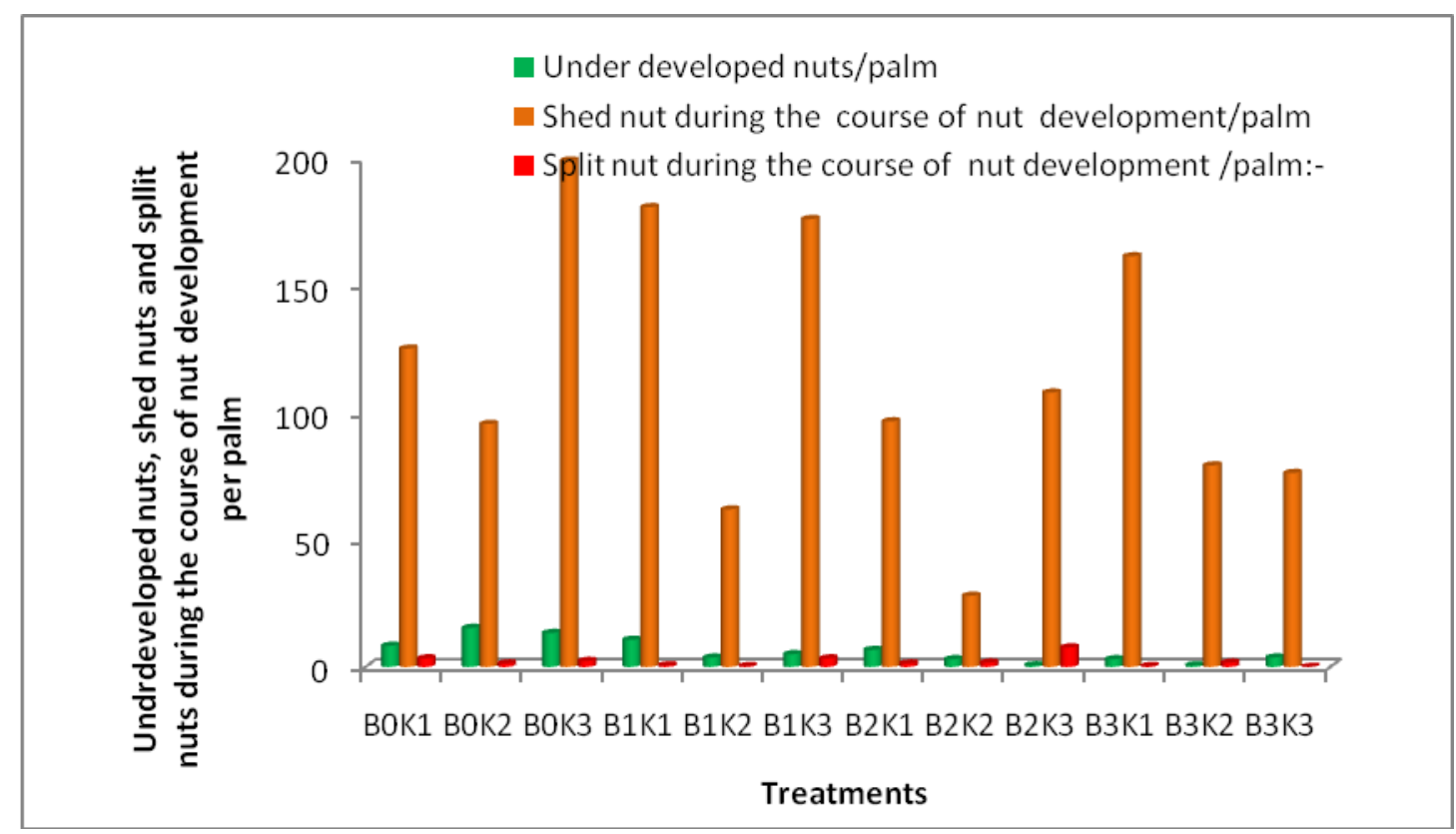

Mehandale et al., (1999) also reported to reduce nut splitting with the application of spray at $0.2 \%$ concentration to the bunches. As per the data obtained from the analysis showed that $B_{2}$ resulted significantly higher split nuts (3.55) compared to $\mathrm{B}_{0}$ and $\mathrm{B}_{1}$ level and $\mathrm{B}_{3}$ (0.66) (Table 1) (Fig. 1) shows significantly lower split nuts which might be due to at higher concentration of boron at experimental soil and additional application resulted boron toxicity as reported by and at different graded levels of potash fertilizers reveal that $\mathrm{K}_{3}$ shows significantly higher split nut (3.33) (Fig. 1) and $\mathrm{K}_{1}$ significantly lower split nut (0.58) (Table 1 and Fig. 1).

The interaction effect of both fertilizer like boron and potassium at different level shows that $\mathrm{B}_{2} \mathrm{~K}_{3}$ (7.66) (Fig. 2) showed significantly higher split nuts and followed by $\mathrm{B}_{1} \mathrm{~K}_{3}$ (3.33) (Fig. 2), In the treatment combination $\mathrm{B}_{2} \mathrm{~K}_{3}$, both the nutrients fails to establish an equilibrium at higher concentration of boron at the experimental soil and it had been reflected in the potassium content of the leaf (1634.73 $\mathrm{mg} / \mathrm{kg}$ ) though both the nutrients were applied at higher dose and $\mathrm{B}_{0} \mathrm{~K}_{3}$ (2.33) (Table 2; Fig 2) but at $B_{0} K_{1}, B_{0} K_{2}$ and $B_{3} K_{3}$ level of application, it does not shows any split nuts, sufficient level of boron in soil favoured the role of potassium and leading to a good result. From the experiment we can conclude that the graded levels of boron and potassium and their interaction indicated that the number of underdeveloped nuts per palm decreased significantly with the increase rate of application of both the nutrients and the combination effect of bunch spraying with moderate application of potassium recorded significantly lowest number of underdeveloped nuts may be due to antagonistic role of boron and potassium at higher level. Shedding of the immature nuts per palm was decreased with increased soil application of boron apart from bunch spraying, and intermediate dose of potassium $\left(\mathrm{K}_{2}\right)$ recorded the lowest shed nuts per palm, while production of splitted nuts per palm responded differently bunch spraying of boron and decreased application of potassium leads 
to lower split nuts,it may be due to because of antagonistic effect, soil status in that terai region and accumulation of leached nutrients in the soil. At higher level of both boron and lower level of potassium recorded significantly lowest split nuts per palm. Under developed nuts and shedding nut population can be decreased by increased application of boron and intermediate application of potassium where as split nut rate has decreased with increased application of boron and decreased application of potassium content to the soil which may be due to presence of soil condition and raining before and after and while collecting information may be linked up with the parameter. Sufficient level of boron in soil favoured the role of potassium and leading to a good result.

\section{References}

Berger, K.C. and Truog, E. (1939). Boron determination in soils and plants. Industrial Engineering Chemistry, 11: 540 - 545.

Bhat and Sujatha, S. (2014). Nutrient management in arecanut. Indian Journal of Arecanut, Spices and Medicinal plants, 16(4).

Bray, R.H. and Kurtz, L.P. (1945). Determination of total, organic and available forms of phosphorus in soils. Soil Science, 59: 39-45.

Jackson, M.L. (1967). Soil Chemical Analysis. Prentice Hall of India Private Limited, New Delhi.

Jackson, M.L. (1973). Soil chemical analysis, Prentice Hall of India, Pvt. Ltd., New Delhi.

Mengel, K and Kirkby, E.A. (2001). Principles of Plant Nutrition. 5th ed. Dordrecth: Kluwer Academic Publishers, pp: 849.

Nathanael, W.R.N. (1967). The application of fertilizer to adult coconut palms in relation to theoretical aspects. Ceylon Coconut Quarterly, 18:1- 30.

Prakash, T.N. (2010). Special scheme on cost of cultivation of arecanut from Karnataka, Department of Agricultural Economics, University of Agricultural Sciences, Bangalore.

Sathya, S., Mahendran, P. P. and Arulmozhiselvan, K. (2013). Availability of nutrients as influenced by boron application in boron deficient soil of Typic Haplustalf. Agricultural Science Digest, 33 (4): 317- 320.

Subbiah, B.V. and Asija, G.L. (1956). A rapid procedure for determination of available nitrogen in soils. Cur. Sci., 25: 259-260.

\section{How to cite this article:}

Supriya, B.V., P. S. Medda and Sinha, A.K. 2019. Interactive and Individual Effect of Boron and Potassium on under Developed Nuts, Shed Nuts and Split Nuts of Arecanut in Terai Region of West Bengal. Int.J.Curr.Microbiol.App.Sci. 8(11): 1664-1671. doi: https://doi.org/10.20546/ijcmas.2019.811.193 